JournEEL

E-ISSN: - Vol. 1 No. 1, June 2019, Page. 52-64

\title{
Role of Philosophy Education for Children in Grade 3 of MINU Pucang Sidoarjo
}

\author{
Fabiola D. Kurnia \\ STKIP PGRI Sidoarjo, Email: fabkurnia@gmail.com \\ Winda Sulistyoningsih \\ STKIP PGRI Sidoarjo, Email: Winnie_t23yummy@yahoo.co.id
}

\begin{abstract}
Philosophical education is needed for children's education. Philosophy as a value education, as well as life education that is very important for the development of human personality. Therefore, philosophical education should be given since elementary school age. The pattern of teaching philosophy applied is different from the teaching patterns of other sciences. Because in philosophy, humans are invited to think critically. In this case what is meant is that they think for themselves and find their own answers to the questions asked. However, philosophy for children should not burden the learning process. Because it must consider the local cultural context that has existed in Indonesia before. The philosophy of early childhood education seeks to uncover and examine the reality of the child's education process. The implementation of early childhood education must be based on philosophy and educational theory that are suitable for child development. Thus, the practice of education has a clear direction, goals that are relevant to the nature, needs and development of children. Children will be treated according to their situation and living conditions.
\end{abstract}

Keywords: Philosophy, Educational Philosophy, Philosophy for Children.

\section{INTRODUCTION}

Children are the smallest person of society who still need guidance in the process of adaptation and learn norms, values, and other things that mean to live their lives as social beings later on. In this regard, education is created, both formal, informal and non-formal. In addition to children getting education from families, children can also attend education in kindergartens which are then continued to elementary school. In this elementary school the child is introduced to the true meaning of education.

Learning how children develop, children learning, and discussing concepts of how to treat and how to teach children is a matter in MINU Pucang or try to know how this school apply the philosophy of children's education. Since some school give the way of teaching with minimal rules of philosophy of children's education.

It is intended that in the future a child can perform his function and role as a human being effectively and productively. Child education experts realize that how important the role of children is, it is necessary to find and find accurate answers about children. 
The philosophy of children's education will answer the following questions (a) what activities are suitable and appropriate to the child's abilities? (b) what needs and abilities do children have to fulfill, and which children develop in community life? (c) what values and morality should be instilled in children to be of value to the community? (d) what is the pattern of the relationship between children and adults?

The philosophy of education conducts in-depth, broad, fundamental studies on the role of education in the development of children and provides the right direction regarding the implementation of children's education. The philosophy of child education is needed to uncover and examine the reality that is happening in the process of children's education. That is why the writer wants to know and observe more.

\section{REVIEW OF LITERATURE}

\section{Philosophy}

Philosophy is the study of general and fundamental problems about problems such as existence, knowledge, values, reason, mind, and language. Historically, "philosophy" covers the core of all knowledge. The methods used in philosophy include asking questions, critical discussion, dialectics, and systematic presentations.

Philosophy also includes the philosophy of education, also has a function to provide guidance and direction in the development of educational theories into educational or pedagogic science. An educational practice that is based and directed by a particular educational philosophy, will produce and give rise to certain forms and symptoms of education. This is educational data that exists in a particular society.

\section{Educational Philosophy}

Philosophy of education is a philosophy of science that studies the nature of implementation and education. The material studied includes the objectives, background, methods, results, and nature of education. The method used is to critically analyze the structure and benefits of education. Education can be divided into two regions, namely humanism and academics.

The side of humanism develops human beings in terms of skills and living practices. While the academic aspects emphasize cognitive values and pure science. Both are important aspects that are actually inseparable. The philosophy of education is 
to continue to analyze and criticize the academic and humanist aspects for the sake of a complete and balanced education. Educational philosophy will continue to review the educational process for the development of education that prints reliable human beings.

The role of the philosophy of education itself is to provide inspiration, namely stating the purpose of state education for the community, providing clear and precise direction by asking questions about education policy and practice in the field by using signs from educator theory.

A teacher needs to master the concepts that will be studied and pedagogy or the science and art of teaching related subject matter, so that there is no misconception or misconception in students. The Relationship Between Philosophy and Science, A new science arises after an assessment in philosophy. Philosophy is a foothold for the activities of forming science. Therefore philosophy is said to be the parent of all fields of science. For the philosophy of education, it is in the interest of building a philosophy of life so that it can be used as a guide in living everyday life, and henceforth, everyday life is always in order. So for education, Philosophy contributes in the form of overall awareness of the origin, existence, and purpose of human life.

\section{Philosophy of Education for Children}

In accordance with what is stated in RI Law No.20 of 2003 article 1 paragraph 1 concerning the National Education System, namely what is meant by education is a conscious and planned effort to realize the learning atmosphere and learning process so that students actively develop their potential to have religious spiritual power, selfcontrol, personality, intelligence, noble character, and skills needed by him, society, nation and country.

Business here means activity or action by mobilizing energy, mind, or body to achieve a purpose. Aware is insyaf, sure, know, and understand. Whereas planned is to develop a system with a certain foundation to be implemented. Educational planning intentionally and truly is needed by education personnel who have overall authority and responsibility for the successful implementation of the education process, especially education in elementary schools. And the application of the philosophy of education in it is a factor that determines and helps the perpetrators of education. 
One that is often talked about today is education that forms aspects of experience. Educational philosophy seeks to answer questions about education policy, human resources, curriculum theory and learning as well as other aspects of education.

One that is criticized concretely is the relationship between educators and students in learning. The role of the philosophy of education for teachers, with the philosophy of metaphysics the teacher knows the nature of humans, especially children so that they know how to treat them and are useful for knowing the purpose of education.

With epistemology philosophy the teacher knows what must be given to students, how to obtain knowledge, and how to convey that knowledge. With the philosophy of axiology the teacher understands what students must obtain not only the quantity of education but also the quality of life because of that knowledge.

What determines the philosophy of education of a teacher is a set of beliefs that are owned and strongly related to teacher behavior, namely: Beliefs about teaching and learning, students, knowledge, and what needs to be known.

\section{Profile MINU Pucang Sidoarjo}

MI Ma'arif (or better known as MINU Pucang Sidoarjo, and now is known as MI Muslimat NU Pucang Sidoarjo) is the most basic level in formal education in Indonesia, equivalent to Elementary School, whose management is carried out by the Ministry of Religion. Education at MINU PUCANG can be reached in 5 or 6 years, because of the acceleration class so that it can spur student learning spirit. Graduates of MINU Pucang can continue their education to Madrasah Tsanawiyah or Junior High Schools and some of them can even enter SBI schools.

The curriculum applied at MINU Pucang is the KTSP curriculum. This Madrasah has high quality with several excellent programs and is able to produce generations that are Islamic and have global insight by providing Imtaq students, Science and Technology, Adab and Skill.

\section{METHOD}

This study uses descriptive qualitative. It described the role of Philosophy of Education for Children in the third grade of ICP, MINU Pucang Sidoarjo. 
The data collection techniques use interview, direct personal investigation or observation, and document.

The data collection instrument of the study is the researcher. Study the theories of the Philosophy of Education for children. Field note was used to note the important things found. Data collection procedures use an in-teractive procedure. These steps were data reduction, data display, and conclusion and verification.

The analysis data use descriptive which is describing the main features of a collection of data. And some documents are collected from the research.

\section{FINDING AND DISCUSSION}

Research is held in MINU Pucang Sidoarjo, specially at grade 3 with number of students 220. Interview is done to 5 homeroom teachers and 1 teacher as the vice of principle. Observation is done to 11 teachers who teach in grade three from 96 teachers totally and 10 education staff.

The writer just observes the activities of students and do not give any treatment. So, totally doing interview and questioning with teachers as the pions of the school.

Based on the results of interviews,

To answer the question of no. 1, Teacher A said, Decorate the class. Environment has a big influence on children's behavior, so the classroom environment must have a positive influence on students. And students are invited to take part in beautifying their class.

The teacher carries out an effective and enjoyable learning process. Students become more interactive because they are active. Like asking questions according to what you want to measure. Enjoy a challenging class competition atmosphere.

Students will feel proud if they have something more than others. So that instincts appear to compete.

Make use of available learning resources. Adequate learning resources and support for the curriculum, related to self-development, and career development. The more diverse and complete the resources available in the class, the greater the tendency of students to love learning.

Help each other in learning. Students often work in a group both heterogeneous and homogeneous, and within the group there is 1 student as a team of experts, so that there is a peer learning process. 
Teacher B said, There are classical discussions in learning. So that students will be encouraged to convey their ideas and opinions. Students are doing study group, present the work or results of his work. Learning how to speak English in their daily activities during at school. They do a study material related to the introduction of a phenomenon that exists in the environment.

Teacher C said, Students do simulation to study material related to the skill of arranging or composing or making things. Example: arranging simple electrical circuits, designing simple planes, making windmills, etc. Sometimes, they do Sociodrama or role playing. Sociodrama and role playing are applied to study material related to character planting. Example: role playing based on a story that contains values of honesty, patience, wisdom, etc.

Teacher D said, Students do demonstrations are applied to study material related to skills in practicing material. Example: poetry reading demonstration, speech reading demonstration, etc.

Doing Interviews can be applied to study material that varies according to the competence of the resource person. Example: interviews with residents, interviews with police, interviews with puskesmas officers, interviews with traders, etc.

Project or Product Making. Project or product making can be applied in learning materials that aim to be able to produce projects or products. Example: bamboo plaiting skills, poster making skills, stove making skills from used goods, etc.

Teacher E said, Students do demonstrations are applied to study material related to skills in practicing material. Example: poetry reading demonstration, speech reading demonstration, etc.

Doing Interviews can be applied to study material that varies according to the competence of the resource person. Example: interviews with residents, interviews with police, interviews with puskesmas officers, interviews with traders, etc.

Project or Product Making. Project or product making can be applied in learning materials that aim to be able to produce projects or products. Example: bamboo plaiting skills, poster making skills, stove making skills from used goods, etc.

Teacher F said, Students do demonstrations are applied to study material related to skills in practicing material. Example: poetry reading demonstration, speech reading demonstration, etc. 
Doing Interviews can be applied to study material that varies according to the competence of the resource person. Example: interviews with residents, interviews with police, interviews with puskesmas officers, interviews with traders, etc.

Project or Product Making. Project or product making can be applied in learning materials that aim to be able to produce projects or products. Example: bamboo plaiting skills, poster making skills, stove making skills from used goods, etc.

To answer the question no. 2, teacher A said, Students need spirit, motivation and support from both parents and teachers. The abbilities should be had by them are soft skill and hard skill in balance. Because they need them to live in society with a good manner ofcourse.

Teacher B said, Students need free to be theirselves. Sometimes parents force them like what the parents wants. And teacher, should know the need of the students in class. Care, share, affection and good manners are the factors to make them aware and understand their job in their daily life.

Teacher C said, There many answers actually. But, the point that they should have is how to survive in this life. People who understand how to survive, they can survive both in their personal life or life with the society or people around them.

Teacher D said, Manners, discipline, responsibility and trustworthiness. If students have these three attitudes, the other attitudes will follow.

Teacher E said, Understand the norms that apply both at home, at school and in society, tolerance, responsibility, love for family, friends, teachers and others.

Teacher F said, Family, Children need families to fulfill their Existence needs, namely the need for shelter, healthy physical condition, and psychological security.

Needs that are transcendent in nature, refer to:

Actions or conditions that arise as a result of affection by giving attention to the interests of many people, experience or process where the child understands himself, a situation where children begin to learn to let go of the ego in the sense of not being selfish. Schools, meanwhile, schools are important containers for fulfilling children's needs for self actualization. Because in school there is an opportunity for children to develop the potential contained in him so that it turns into a real ability.

The community that I am referring to here is not only the community environment in general around the residence but also refers to the religious community. In society, 
children develop their social potential. In society also children can show strength, need for power. If education in the family does not accommodate this or not in proper education, this need will be fulfilled but negative.

To answer question no.3, teacher A said, Manners, obedience and respect for parents and older people. Love the younger. Pray 5 times and prioritize on time. And always spread kindness in society.

Teacher B said, The embeded of moral values aims to instill moral values that begin to fade in the environment of children due to the bad influence they get so that children in the future are expected to have good morals. Religious values, independence values, social values, honesty, responsibility and fighting spirit need to be instilled in students.

Teacher C said, Religious values, the value of sociality, gender values, the value of justice, the value of democracy, the value of honesty, the value of independence, the value of fighting power, the value of responsibility, and the value of respect for the environment. The way to instill these values is to insert into all the subjects taught, through the school environment and collaboration with parents.

Teacher D said, Discipline, keep the environment clean, including not disposing of garbage in its place, on time in any way, whether at home, at school, or in terms of community.

Teacher E said, Having fighting power, teaching courage and sportsmanship, this is seen when in the classroom students dare to even fight to advance to the board to solve the problem and dare to express their opinions. Healthy living, by teaching healthy living will create a clean and comfortable learning environment. And courtesy is something that really needs to be taught to students because in daily life students must be polite to both the teacher and his friends.

Tacher F said, First, the teacher instills moral values in students by inserting moral values, namely religious values, social values, gender values, justice values, democratic values, honesty values, independence values, fighting values, values of responsibility, and values of respect for the environment to all subjects taught. Second, most students do not lie to the teacher because they instill honesty values. Third, the relationship between students and their friends is good, fourth, to deepen the knowledge of religion in addition to religion in schools, also to study at the recitation place and TPA. 
The moral values that should be given to students in Lampeuneurut Public Elementary School is mostly good because the teacher has instilled moral values into students even though there are some teachers who do not fully know the values that must be instilled. Then instill moral values of all subjects, give advice every day, teachers become role models of students, through the school environment and cooperation with parents.

To answer question no. 4, teacher A said, Tolerance-intolerance, the attitude of parents who are full of tolerance, allows children to be able to have a strong ego. Conversely, intolerance tends to produce a weak ego in the child. Permissiveness strictness, can form to support the process of forming children's intellectual control, but on the contrary violence has an impact on the formation of impulsive children's personalities. Involvement - detachment, a child tends to become extroverted, when parents can show an attitude of involvement and care. Conversely, the attitude of parents who are too letting have an impact on the formation of personal introverted children. Warmth - Coldness, Parent-child relationships that are characterized by warmth allow children to have the ability to be able to involve themselves in their social environment. Conversely, cold parent-child relationships will cause children to always withdraw from their social environment.

Teacher B said, In an effort to meet children's self-esteem needs, parents can provide opportunities for children to learn to be responsible and determine themselves. Here, parents only act as facilitators, who strive to provide broad opportunities for children to reach their self-esteem through developing their interests and skills.

A child becomes anti-democratic, prejudice, and has an attitude of hostility from the attitude of a strict parent.

Teacher C said, If parents are over-protective, then the child will have an aggressive attitude, not comfortable with himself and his environment, very dependent, want to be the center of attention, and others. If parents spoil the child too much, the result will be a childwho is a claimant, self-won, spoiled and dependent, and so on.

Conversely, if parents educate at home in the right way, and in line with what is taught in school, then the result, the child will be good and not prosecutor.

Teacher D said, Development and growth of children is basically very influenced by education from the family environment, because the position of the family in the 
development of children's personality is very dominant. In addition, the conditions of social and cultural interaction potentially also influence the development of religious nature or religious awareness of each child. So that the provision of early childhood education is mainly given in the family environment (informal environment), then new in the formal environment, namely the school and the non-formal environment of children (playing groups or the like).

Teacher e said, Bustle; In the modern era like now, many activities are carried out outside the number of family togetherness. Children will spend more time with their peers, busy themselves outside seeing what parents show.

Convenience; Comfort is formed because of a sense of understanding with each other.

Communication; The difficulty of communicating should be a big question mark for parents. By freeing children to know the outside world, to forget the role of parents as the main communicant that is good for their children. All children feel their own pleasure when their parents pay attention that parents don't realize they really need.

Trust; By instilling trust from the family, a child will maintain a trust that is comparable to the child's trust in their parents. Because, if both of them have trusted each other in positive terms then the results are positive.

Teacher F said, Parenting is an interaction between parents and children in communicating, educating, nurturing, and continues over time. With parenting applied, parents can interact with the environment about the world around them and get to know the life relationships that apply in their environment. Authoritative, authoritarian and primitive patterns of parents used to nurture children based on the care, demand, communication and control of children's behavior.

Based on the observation that the writer do, the third grade of MINU Pucang are; for teachers and educators in general, the philosophy of education is very necessary because its actions to educate and teach will always be influenced by the philosophy of life and by the philosophy of education adopted.

Philosophy of education will give direction to its teaching and teaching. For example in preparing school curriculum, teachers must clearly formulate the curriculum objectives, and for that he must refer to his educational philosophy. his treatment of students is his philosophy of relection. his teaching style will also be influenced by his 
philosophy adopted. a teacher should have a clear philosophy of life and a philosophy of education that is part of his personality .

The philosophy of physical education is also related to the development of all aspects of teaching. By placing the philosophy of education at the practical level, elementary school teachers can find various solutions to educational problems.

And MINU Pucang has applied the education to children in elementary school level. There are many programs which have been run by this school. Students are taught about how to behave well in school, home and society. The characters of the students are becoming the first focus of MINU Pucang. How they behave when they are in school, home or in society. Kinds of adab or ethiquettes are learnt by them. Including how to perform well in worship side to be more religious.

Then some academic program to dig the students' potencies. A programs for excellent students, for lower level students, and special class for competition outside. They are taught how to study well and give some questions or try out to face time when they are in the sixth grade. English camp for students and teachers too. And many other programs are applied for students.

There are also some programs for teachers, especially how to increase the teachers' quality. Every Saturday, there are teachers working group. Sometimes they hold a worshop for teachers. We call it by KKG (Kelompok Kerja Guru) in MINU Pucang. This KKG is for all teachers, there is another KKG. It is smaller group of teacher. There is special $\mathrm{KKG}$ in each grade, from grade one until grade six have different discussion and works. There is also English KKG special to improve teachers' ability in English because MINU Pucang is an International School Examination. So, some programs like this are needed.

\section{CONCLUSION}

The students of third grade in MINU Pucang have enjoyed the process of learnings. They are discipline, responsible and aktive in the class. While, there are still some trouble maker in the class but still in normal bahavior.

Many activities are suitable and appropriate to the children's abilities to equip children how to survive, how to behave at home, school and society. The students needs many things and some abilities and which they should be able to develop 
theirselves in community life. They are used to solve problems from the lessons or subjects they get, from the addition program, entrepreneur, etc.

The values and morality they should be instilled to be of value to the community have been taken. Teachers has taught to the students about the values and morality through learning process. They are not $100 \%$ good based on the vission and mission of the school. They need process. And the process is not easy for them. But they still keeps spirit even they should go to school at 6 in the morning, and reach home at six in the night or even more.

School doesn't only have program between teachers and students only, they also have the program for monitoring the students at home. To teach the role and the pattern of the relationship between children and parents. Such as daily agenda, a group for techers and parents to ease them to discuss and talk about the students develoment at school and also for important information about school to children. Because parents need to know.

And at least every once a year, there is a program a day synchronization where the students, teachers and parents are facing together to know the development of habit, ettiquete or behavior of the children at home, that the teachers should know from the parents to be followed up.

\section{REFERENCES}

A.C. Grayling, Philosophy 1: A Guide through the Subject (Oxford University Press, 1998), p. 1: "The aim of philosophical inquiry is to gain insight into questions about knowledge, truth, reason, reality, meaning, mind, and value."

Adler, Mortimer J. (28 March 2000). How to Think About the Great Ideas: From the Great Books of Western Civilization. Chicago, Ill.: Open Court.

Depdikbud. 1989. UU RI no. 20 tahun 2003 tentang sistem pendidikan nasional beserta penjelasannya. Jakarta: balai pustaka.

Dewey, John (2008). Pengalaman dan Pendidikan. Yogyakarta: Kepel Press.

Etymological Dictionary. Accessed on $19^{\text {th }}$ March 2016. The English word "philosophy" is first attested to c. 1300, meaning "knowledge, body of knowledge."

Hidayat, Rakhmat (2013). Pedagogi Kritis. Jakarta: Raja Grafindo Persada. hlm. 2. 
Mudyahardjo, Redja (2008). Filsafat Ilmu Pendidikan. Bandung: Rosda. hlm. 5-10.

Muhmidayeli (2011). Filsafat Pendidikan. Bandung: Refika Aditama.

Kuswana, Wowo Sunaryo (2013). Filsafat Pendidikan Teknologi, Vokasi dan Kejuruan.

Bandung: Alfabeta 